\title{
Karakteristik Mufffin dengan Penambahan Puree Pisang Tongka Langit (Musa troglodytarum)
}

\section{Characteristics of Muffin with the Addition of Tongka Langit Banana (Musa troglodytarum) \\ Puree}

\section{Helen C. D. Tuhumury*, Agustina Souripet, Michael Warlauw}

Jurusan Teknologi Hasil Pertanian Fakultas Pertanian Universitas Pattimura, Jl. Ir. M. Putuhena Kampus Poka Ambon 97233, Maluku, Indonesia

*Penulis korepondensi: Helen C.D. Tuhumury, e-mail: hcdtuhumury@gmail.com

Tanggal submisi: 10 Juni 2020; Tanggal penerimaan: 01 September 2020

\begin{abstract}
This research was aimed to determine the effect of different tongka langit banana puree concentration on the physical, chemical, and sensory characteristics of muffin and determine the exact concentration of muffin with the best quality. A complete randomized experimental design with four levels of concentrations, i.e. $0 \%$ (control), 70\%, 80\%, and 90\% was applied in this research. Results showed that the best physical, chemical, and sensory properties of muffins were obtained with the addition of $80 \%$ tongka langit banana puree. A muffin with this respective concentration had an expansion volume of $118 \%$, moisture, ash, vitamin, and total sugar contents of $26.09 \%, 1.56 \%, 0.60 \%$, and $15.10 \%$, subsequently. Based on its sensory characteristics, muffin with $80 \%$ banana puree was mostly preferred by panelists on aroma and overall likeness. The sensory characteristics of tongka langit banana were also maintained in the muffin.
\end{abstract}

Keywords: muffin, physicochemical, sensory, tongka langit banana puree

\begin{abstract}
ABSTRAK
Penelitian ini bertujuan untuk menentukan pengaruh konsentrasi puree pisang tongka langit terhadap karakteristik fisik, kimia dan organoleptik muffin dan menentukan konsentrasi puree yang tepat yang menghasilkan muffin dengan karakteristik terbaik. Rancangan Acak Lengkap dengan faktor tunggal konsentrasi puree pisang tongka langit dengan level $0 \%$ (kontrol), $70 \%, 80 \%$, dan $90 \%$ digunakan dalam penelitian ini. Hasil penelitian menunjukkan bahwa puree dengan konsentrasi $80 \%$ merupakan perlakuan yang tepat untuk menghasilkan muffin dengan karakteristik terbaik secara fisik, kimia dan organoleptik. Muffin dengan puree pisang tongka langit $80 \%$ memiliki volume pengembangan $118 \%$, kadar air 26,09\%, kadar abu $1,56 \%$, kadar vitamin C $0,60 \%$, total gula $15,10 \%$ dan lebih disukai panelis pada kategori aroma dan overall serta lebih mempertahankan karakteristik pisang tongka langit pada muffin.
\end{abstract}

Kata Kunci: fisikokimia, muffin, organoleptik, puree pisang tongka langit 


\section{PENDAHULUAN}

Produk-produk bakery merupakan salah satu bagian penting dari pola makan yang seimbang. Dewasa ini sudah banyak jenis produk ini yang tersebar luas di pasaran dan supermarket. Produk bakery antara lain poduk roti, muffin, donat, pancake pie, kue, pastry, biskuit/cookies. Salah satu produk bakery yang cukup banyak dikonsumsi masyarakat saat ini adalah muffin. Produk muffin cukup popular karena dinilai praktis dan memiliki cita rasa cukup baik. Muffin merupakan produk bakery yang berasal dari Inggris dan saat ini telah banyak dikenal oleh masyarakat Indonesia. Muffin tergolong jenis quick breads yaitu produk bakery yang dibuat tanpa melalui proses fermentasi. Muffin memiliki ciri khas yaitu permukaan crust yag merekah serta simetris, crust berwarna coklat keemasan, pori crumb tidak halus namun ukuran seragam, ringan, lembut, lembab serta tidak membutuhkan volume pengembangan yang besar (Shevkani dan Singh, 2014; Matos et al., 2014).

Muffin memiliki kelemahan yaitu memiliki kandungan serat yang rendah. Berbagai penelitian mengenai muffin lebih banyak diarahkan untuk mengurangi penggunaan tepung terigu dengan penggunaan tepung komposit yang lain seperti tepung labu kuning (Rismaya et al., 2018); tepung ganyong (Hanani, 2015), tepung pisang goroho (Albanjar et al., 2017). Penggunaan tepung pisang terutama pada produk muffin memiliki kelemahan yaitu memiliki aroma pisang yang kurang kuat. Oleh sebab itu dilakukan pengembangan muffin dengan menggunakan puree buah. Pengembangan produk muffin dengan menggunakan puree buah sudah banyak dilakukan antara lain puree advokat (Othman et al., 2018), puree labu kuning (Arifin et al., 2019), puree buah ara (Hartley et al., 2017).

Permasalahan kurangnya aroma pisang pada muffin dapat diatasi dengan penggunaan puree. Salah satu jenis pisang endemik Maluku yaitu pisang tongka langit berpotensi dikembangkan sebagai produk antara puree (Lahane, 2019; Tuhumury et al., 2018). Pisang tongka langit (Musa troglodytarum L.) merupakan salah satu komoditi hasil pertanian asli Maluku yang memiliki ciri khas yakni tandannya tegak menengadah ke langit. Hal ini merupakan salah satu ciri yang membedakan pisang tersebut dengan jenis pisang lainnya. Getah batang pohonnya yakni berwarna merah muda sampai ungu tua (Hakkinen et al.,2012). Warna oranye kemerahan pada kulit buah dan warna kuning oranye pada daging buah pisang tongka langit memberikan indikasi adanya senyawa karotenoid (Engelberger, 2003).

Menurut Engelberger (2003), Fei banana yang sejenis dengan pisang tongka langit mengandung kadar provitamin A dan total karotenoid yang sangat tinggi, yaitu mencapai $6360 \mu \mathrm{g} / 100 \mathrm{~g}$. Pisang ini yang diolah dengan cara dimasak memiliki kandungan $4960 \mu \mathrm{g}$ betakaroten ekuivalen/100 g. Dengan demikian hanya dengan mengonsumsi $250 \mathrm{~g}$ pisang tongka langit tiap hari, maka akan diperoleh $2067 \mu \mathrm{g}$ RE (retinol ekuivalen) yang sudah memenuhi kebutuhan vitamin A per hari yang cuma $500 \mu \mathrm{g}$ per hari. Sedangkan hasil penelitian Samson et al. (2013) menunjukkan bahwa pisang tongka lagit mengandung $\beta$-karoten dengan menggunakan Near InfraRed Spectroscopy. Menurut Samson et al. (2019) jus pisang tongka langit mampu mengatasi infeksi Plasmodium berghei serta akibat kerusakan yang ditimbulkannya sehingga ginjal mencit dapat kembali berfungsi normal.

Manfaat kesehatan dari pisang tongka langit membuatnya memiliki prospek untuk digunakan sebagai bahan baku pembuatan muffin. Penggunaan puree pisang tongka langit diperkirakan lebih baik karena manfaat kesehatan buah ini lebih banyak didapatkan pada buah yang sudah matang sekali, sedangkan untuk pembuatan tepung, pisang yang digunakan belum mencapai tingkat kematangan buah pisang tongka langit yang biasa dikonsumsi. Penggunaan puree pisang sudah dilakukan dalam pembuatan muffin dalam hal ini puree pisang ambon (Astasari, 2016) untuk mengatasi masalah diatas. Hal ini mungkin karena pada pembuatan muffin tidak diharapkan pembentukan gluten yang besar. Pembentukan gluten yang besar pada produk bakery akan meningkatkan viskoelastisitas gluten menyebabkan produk memiliki memiliki pori-pori yang besar dan tidak seragam (El Khoury et al., 2018; Tuhumury et al., 2014) dan hal ini tidak diinginkan untuk produk muffin. Hasil penelitian Astasari (2016) menunjukkan bahwa puree 50\% menggantikan tepung terigu menghasilkan muffin dengan karakteristik terbaik. Penggunaan bahan non terigu dalam pembuatan muffin dapat memengaruhi karakteristik mutu muffin yang dihasilkan.

Dengan demikian, penambahan puree pisang tongka langit dengan proporsi lebih dari $50 \%$ ke dalam formulasi muffin diduga dapat mempengaruhi karakteristik muffin yang dihasilkan, sehingga diperlukan penelitian untuk mengetahui pengaruhnya terhadap karakteristik fisikokimia dan 
organoleptik muffin. Penelitian ini bertujuan untuk menentukan pengaruh penambahan puree pisang tongka terhadap karakteristik muffin. Penelitian ini merupakan hal yang baru dalam pengembangan produk muffin yang menggunakan puree dan bukan tepung dari jenis pisang endemik Maluku.

\section{METODE PENELITIAN}

\section{Bahan}

Bahan yang digunakan dalam penelitian ini adalah buah pisang tongka langit jenis panjang dari Desa Hunut, Kecamatan Teluk Ambon, Kota Ambon dengan tingkat kematangan komersial (10 hari setelah panen) serta memiliki warna daging buah sesuai dengan warna Egg Yolk Colour Chart No 10.

\section{Rancangan Percobaan}

Rancangan percobaan yang digunakan dalam penelitian ini adalah rancangan acak lengkap yang terdiri dari satu faktor yakni konsentrasi penambahan purre pisang tongka langit dengan 4 taraf perlakuan: $0 \%$ (control), 70\%, 80\%, dan 90\%. Masing-masing perlakuan diulang sebanyak dua kali sehingga jumlah satuan percobaan adalah 8 satuan percobaan. Analisis keragaman digunakan untuk menentukan pengaruh perlakuan dan jika ada pengaruh yang nyata dilanjutkan dengan Uji Tukey pada taraf $\alpha=0,05$.

\section{Pembuatan Puree dan Muffin}

Pisang tongka langit dari tandan yang memiliki warna daging sesuai egg yolk colour no 10 dalam keadaan utuh dibakar selama 5 menit untuk menonaktifkan enzim polifenoloksidase. Pisang kemudian dikupas dan dihancurkan hingga lembut dengan menggunakan ayakan.

Tepung terigu serbaguna (Kompas) $200 \mathrm{~g}$, soda kue (Koepoe Koepoe) 6 g, baking powder (Koepoe Koepoe) $4 \mathrm{~g}$ dicampur dan disisihkan. Margarin (Blueband) $100 \mathrm{~g}$ dilelehkan dan disisihkan. Telur $100 \mathrm{~g}$, gula $100 \mathrm{~g}$, vanili 2,5 mL dan garam dikocok sampai mengembang kemudian dicampur dengan tepung terigu 200 g, soda kue, baking powder yang tadi sudah tercampur dan margarin yang sudah dilelehkan kemudian dicampur dan diaduk rata dan ditambahkan puree pisang tongka langit sesuai perlakuan. Setelah semua bahan tercampur, dituangkan ke dalam cup.
Tahap yang berikut dimasukkan dalam oven lalu dipanggang hingga matang 200-210 ${ }^{\circ} \mathrm{C}$ dalam waktu 1 jam menurut metode Astasari (2016) yang dimodifikasi.

\section{Volume Pengembangan}

Analisis volume pengembangan mengacu pada metode seed displacement (Krisnawati, 2014) termodifikasi. Volume pengembangan merupakan perbandingan antara volume adonan muffin sebelum dipanggang dengan volume muffin sesudah dipanggang. Volume muffin diukur menggunakan metode seed displacement dengan biji-bijian chia. Biji chia dimasukkan ke dalam wadah pengukuran hingga penuh rata. Setelah wadah terisi penuh, sebagian biji dipindahkan sementara ke wadah lain, lalu muffin dimasukkan ke dalam wadah dan dipenuhi kembali dengan biji chia dari wadah lain hingga penuh rata. Sisa biji chia diukur dengan gelas ukur sebagai volume muffin. Volume adonan ditentukan dengan menggunakan gelas ukur yaitu adonan muffin terlebih dahulu dimasukkan ke dalam gelas ukur lalu volumenya dicatat.

\section{Kadar Air (AOAC, 1995)}

Metode thermogravimetri digunakan untuk menentukan kadar air. Cawan timbang dipanaskan dalam oven (Memmert, Germany) selama 30 menit pada suhu $100-105^{\circ} \mathrm{C}$ kemudian didinginkan selama 15 menit dalam desikator. Beratnya ditimbang menggunakan timbangan analitik (Ohaus, USA). Sampel sebanyak 2 g dimasukkan dalam cawan timbang dan dikeringkan dalam oven selama 6 jam. Cawan dan sampel didinginkan dalam desikator dan ditimbang beratnya. Prosedur diulang sampai mendapatkan berat yang konstan. Banyaknya air yang diuapkan dihitung dari selisih berat sampel sebelum pengeringan dan berat sampel setelah dikeringkan.

\section{Kadar Abu (AOAC, 1995)}

Cawan porselen dipanaskan dalam oven (Memmert, Germany) selama 15 menit, kemudian didinginkan dalam desikator dan ditimbang. Sampel sebanyak $5 \mathrm{~g}$ dimasukkan dalam cawan porselen dan ditimbang, lalu dibakar sampai tidak berasap lagi dan diabukan dalam tanur (Vulcan A $550 \mathrm{Ney}$, USA) bersuhu $550^{\circ} \mathrm{C}$ sampai semua sampel menjadi abu. Setelah itu didinginkan dalam 
desikator dan ditimbang sampai mendapatkan bobot konstan.

Total Gula (Apriyantono, 1989)

Larutan sebanyak $1 \mathrm{~mL}$ dimasukkan tabung reaksi yang berisi $5 \mathrm{~mL}$ anthrone $(0,05 \mathrm{~g}$ dalam 50 $\mathrm{mL} \mathrm{H}_{2} \mathrm{SO}_{4}$ pekat) kemudian ditutup dengan plastik, dihomogenkan, dan dipanaskan pada suhu $100^{\circ} \mathrm{C}$ selama 12 menit, setelah itu didinginkan dengan cepat pada air mengalir, dibaca pada panjang gelombang $630 \mathrm{~nm}$ (Spektrofotometer UV-VIS, Shimadzu, Japan).

$$
\text { Total gula }(\%)=\frac{x \text { pengenceran }}{\text { berat sampel }(\mathrm{mg})} \times 100
$$

\section{Vitamin C (Metode Titrasi Iodometri)}

Muffin sebanyak $5 \mathrm{~g}$ dihaluskan dengan mortar dan dimasukkan dalam labu ukur $100 \mathrm{~mL}$ dan ditambahkan akuades sampai batas. Sampel didiamkan selama 15 menit sambil dikocok dan kemudian disaring. Filtrat disiapkan sebanyak 25 $\mathrm{mL}$ dalam erlemeyer bersih dan kering. Filtrat ditetesi beberapa indikator kanji $1 \%$ kemudian titrasi dengan larutan Iod 0,01 N sampai terbentuk warna biru. Perhitungan kadar vitamin $\mathrm{C}$ dilakukan berdasarkan kurva standar. Vitamin C per $100 \mathrm{~g}$ bahan dihitung dengan rumus:

$$
\text { Vitamin C per } 100 \mathrm{~g}=\frac{m L \text { penitar } \times N \text { iodium } \times \frac{0,88}{0,01} \times \mathrm{fp}}{\text { berat sampel }}
$$

Keterangan: $\mathrm{N}=$ Normalitas, $\mathrm{fp}=$ faktor pengenceran

\section{Pengujian organoleptik (Setyaningsih et al., 2010)}

Pengujian organoleptik muffin secara hedonik dilakukan terhadap warna, rasa, aroma, tekstur, overall. Mutu hedonik dilakukan terhdap parameter rasa, tekstur, warna dan aroma. Panelis agak terlatih sebanyak 20 orang digunakan dalam pengujian ini. Kriteria penilaiannya sangat suka = 4; suka $=3$; agak suka $=2$ dan tidak suka $=1$. Karakteristik mutu hedonik dapat dilihat pada Tabel 1.

\section{HASIL DAN PEMBAHASAN}

Muffin dengan penambahan puree pisang tongka langit yang berbeda sesuai perlakuan dianalisis karakteristik fisik, kimia, dan organoleptiknya. Hasil produk muffin dapat dilihat pada Gambar 1.

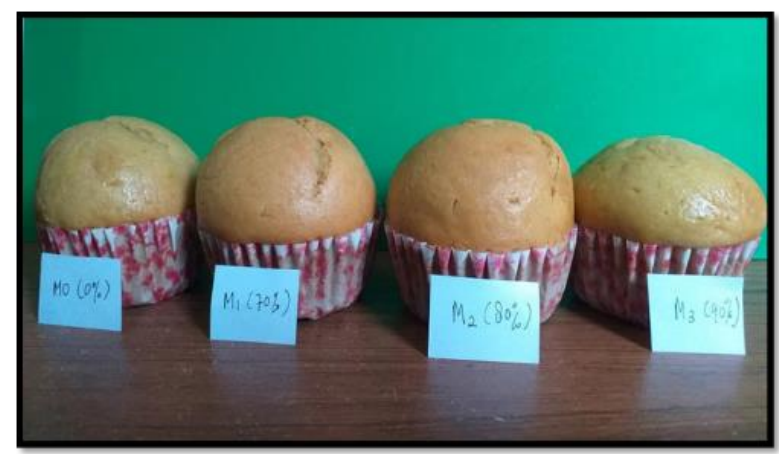

Gambar 1. Muffin dengan konsentrasi puree pisang tongka langit yang berbeda

\section{Karakteristik fisik muffin}

\section{Volume pengembangan}

Volume pengembangan merupakan salah satu parameter penting dalam penerimaan produk muffin. Pengembangan volume yang besar mencerminkan struktur yang lebih berongga dan berpori, sehingga dapat diterima dengan baik. Hasil analisis ragam terhadap peubah volume pengembangan menunjukkan bahwa perlakuan konsentrasi puree pisang tongka langit tidak berpengaruh nyata terhadap volume pengembangan muffin yang dihasilkan. Volume pengembangan muffin dengan konsentrasi puree yang berbeda dapat dilihat pada Gambar 2 .

Hal ini menunjukkan bahwa volume pengembangan muffin dengan penambahan puree pisang tongka langit sampai $90 \%$ tidak berbeda nyata dengan muffin kontrol. Rata-rata volume pengembangan berkisar antara 166,25\%-181,88\%.

Penelitian muffin dengan penambahan tepung komposit lainnya menunjukkan bahwa makin banyak rasio tepung lain selain terigu mengakibatkan penurunan persentase volume pengembangan karena penurunan jaringan gluten. Jaringan gluten berperan dalam pengembangan produk untuk menahan gas $\mathrm{CO}_{2}$, sehingga terbentuk pori-pori dan menghasilkan produk yang mengembang setelah pemanggangan (Wulandari dan Lembong, 2016).

Penambahan puree cenderung meningkatkan volume pengembangan walaupun secara statistik tidak berbeda dengan yang tanpa penambahan. Hasil penelitian Manaf et al. (2016) menunjukkan bahwa penambahan puree buah alpukat tidak mempengaruhi struktur porinya, sehingga volume pengembangannya juga tidak terpengaruh. 


\section{Tabel 1. Karakteristik Mutu Hedonik Mufffin}

\begin{tabular}{lrllll}
\hline Nilai & $\begin{array}{c}\text { Nilai skala } \\
\text { grafik }\end{array}$ & \multicolumn{1}{c}{ Warna } & \multicolumn{1}{c}{ Rasa } & Tekstur & \multicolumn{1}{c}{ Aroma } \\
\hline 1 & $1,00-1,99$ & Tidak & Tidak berasa pisang & Tidak & Tidak beraroma pisang tongka \\
& & kuning & tongka langit & lembut & langit \\
Agak berasa pisang & Agak & Agak beraroma pisang tongka \\
& $2,00-2,99$ & $\begin{array}{l}\text { Agak } \\
\text { kuning }\end{array}$ & $\begin{array}{l}\text { tongka langit } \\
\text { lembut }\end{array}$ & $\begin{array}{l}\text { langit } \\
\text { Berasa pisang tongka }\end{array}$ & $\begin{array}{l}\text { Lembut } \\
\text { Beraroma pisang tongka langit }\end{array}$ \\
3 & $3,00-, 3,99$ & Kuning & $\begin{array}{l}\text { langit } \\
\text { Sangat berasa pisang }\end{array}$ & $\begin{array}{l}\text { Sangat } \\
\text { lembut }\end{array}$ & $\begin{array}{l}\text { Sangat beraroma pisang } \\
\text { tongka langit }\end{array}$ \\
\hline
\end{tabular}

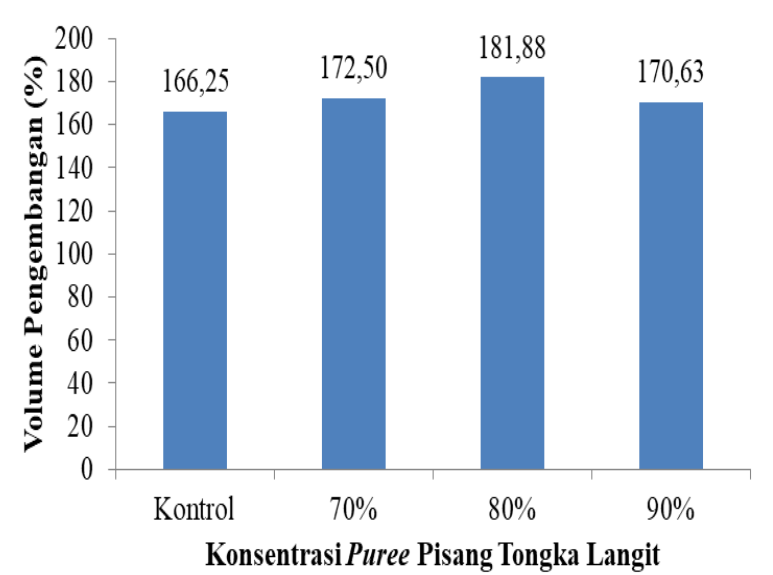

Gambar 2. Volume pengembangan muffin dengan konsentrasi puree yang berbeda

Puree pisang tongka langit memiliki kadar air yang cukup tinggi sekitar 76\% (Lahane, 2019). Keberadaan air dalam adonan juga diduga mempengaruhi karakteristik reologi adonan dan kualitas produk akhir. Air dalam adonan selain membantu pembentukan struktur gluten juga penting dalam gelatinisasi pati selama pemanasan. Proses ini penting dalam pembentukan struktur cake (Wilderjans et al., 2008). Volume muffin juga ditentukan oleh kandungan amilosa dan peranan amilosa dalam pembentukan struktur remahnya (Acosta et al, 2011). Peningkatan derajat gelatinisasi menyebabkan semakin banyak amilosa yang lepas dari granula pati, yang berfungsi sebagai pengikat yang bersama dengan jaringan gluten dapat menghasilkan massa adonan elastik. Adonan yang bersifat elastik ini berperan dalam pembentukan jaringan kerangka muffin yang dapat didesak oleh gas selama proses pemanggangan sehingga volumenya mengembang.

\section{Karakteristik kimia muffin}

\section{Kadar air}

Kadar air muffin dengan konsentrasi puree yang berbeda berada pada kisaran 19,76\%-26,97\% . Kadar air tertinggi diperoleh dari muffin dengan konsentrasi $90 \%$ dan berbeda nyata dengan semua perlakuan. Sedangkan kadar air terendah pada muffin kontrol (tanpa penambahan puree pisang tongka langit). Kadar air muffin dengan konsentrasi puree pisang yang berbeda dapat dilihat pada Tabel 2.

Meningkatnya kadar air muffin dengan meningkatnya konsentrasi puree karena puree pisang tongka langit memiliki kadar air yang tinggi antara 75\%-77\% (Lahane, 2019). Dengan demikian semakin tinggi konsentrasi puree yang ditambahkan kadar air muffin makin tinggi. Kisaran kadar air ini sesuai untuk kadar air produk cake yang biasanya berada diantara 15-30\% (Conforti, 2006). Hasil yang diperoleh ini berbeda dengan kadar air muffin yang dibuat dengan penambahan tepung yang lain dimana makin tinggi konsentrasi tepung yang ditambahkan makin rendah kadar airnya (Rismaya, 2018).

Makin banyak puree yang ditambahkan kadar air muffin makin tinggi kadar air. Hal ini disebabkan puree juga mengandung air bebas yang tidak terikat pada molekul karbohidrat maupun protein yang ada dalam matriks muffin, sehingga saat pengeringan, makin banyak air bebas yang diuapkan sebagai kadar air muffin.

\section{Kadar abu}

Kadar abu muffin berkisar antara 1,30\%1,57\%. Kadar abu muffin dapat dilihat pada Tabel 2. Kadar abu berhubungan dengan kandungan mineral dalam bahan. Abu sisa pembakaran pada analisis kadar abu menunjukkan banyaknya kandungan zat anorganik dalam produk tersebut, 
sedangkan yang menguap menunjukkan kandungan zat organik. Biasanya komponen tersebut terdiri dari kalsium, kalium, natrium, besi, mangan, magnesium, dan iodium. Unsur-unsur mineral tersebut di dalam tubuh berfungsi sebagai zat pembangun dan pengatur. Beberapa penelitian muffin dengan menggunakan penambahan tepung lain seperti bubuk daun kelor (Srinivasamurthy et $a l .$, 2017), bubuk jagung muda (Jauhara et al., 2014), bubuk rumput laut (Mamat et al., 2018) menunjukan bahwa kandungan abu muffin dikarenakan kandungan senyawa-sennyawa anorganik dan mineral yang terkandung di dalamnya. Kadar abu yang sedikit pada pure pisang tongka langit, menyebabkan perbedaan kadar abu pada muffin juga tidak berbeda nyata meskipun kadar pure yang digunakan semakin meningkat. Hasil penelitian Tetelepta et al. (2015) menyatakan bahwa pengolahan pisang tongka langit dengan cara dibakar memiliki kadar abu terendah yakni $1.58 \%$. Dalam penelitian ini pun digunakan metode pengolahan pisang tongka langit dengan cara dibakar, dengan demikian kadar abu puree yang dihasilkan juga rendah.

\section{Total gula}

Hasil penelitian menunjukkan bahwa total gula muffin pada perlakuan tanpa penambahan puree pisang tongka langit sebesar $14 \%$. Perlakuan penambahan puree dengan sebanyak 90\% memiliki kadar total gula yang tinggi yaitu $17.42 \%$, sedangkan total gula terendah terdapat pada muffin yang dibuat tanpa penambahan puree pisang tongka langit dan tidak berbeda nyata dengan muffin yang dibuat dengan penambahan puree pisang sebanyak $70 \%$ dan $80 \%$. Perbedaan total gula muffin yang diperoleh diduga disebabkan karena penambahan puree pisang tongka langit yang berbeda pada tiap perlakuan. Menurut Tetelepta et al. (2015), perlakuan pengolahan buah pisang dengan cara bakar memiliki kadar total gula $9,49 \%$. Sedangkan bahan yang lain seperti gula pasir dan terigu juga akan memberikan sumbangan terhadap total gula, akan tetapi diasumsikan sama pada semua perlakuan karena jumlah yang ditambahkan untuk semua perlakuan adalah sama. Total gula juga menyumbang pada pembentukan warna muffin akibat dari reaksi Maillard antara gula reduksi dan gugus amino dan karamelisasi (Purlis, 2010).

\section{Vitamin C}

Vitamin C merupakan senyawa bioaktif yang mengandung gugus senyawa asam askorbat. Asam askorbat merupakan senyawa bioaktif secara fisiologis dan biokimia larut dalam air. Asam askorbat tidak dapat disintesis dalam tubuh dan jika terkena sinar matahari (UV) secara langsung maka akan terjadi proses oksidasi fotolisis yang mampu mengubah asam askorbat tereduksi menjadi dehidroaskorbat (Caramena dan Wang, 2016; Abbas et al, 2012). Selain oleh sinar matahari, vitamin $\mathrm{C}$ juga bisa rusak karena adanya panas dan logam. Dengan demikian, proses pemasakan juga dapat menurunkan kandungan vitamin C. Penggunaan puree pisang tongka langit dalam penelitian ini juga meningkatkan kadar vitamin $\mathrm{C}$ dari muffin yang dihasilkan. Pengaruh nyata terlihat pada kandungan vitamin $\mathrm{C}$ dari muffin tanpa penambahan puree pisang tongka langit dengan yang menambahkan puree, akan tetapi tidak menunjukkan pengaruh nyata pada sesama muffin yang dibuat dengan penambahan puree pisang tongka langit. Nilai kadar vitamin $\mathrm{C}$ dapat dilihat pada Tabel 2.

Meskipun berbeda konsentrasi yang digunakan yakni puree $70 \%, 80 \%$, dan $90 \%$ dari berat tepung terigu tetapi menghasilkan muffin yang kadar vitamin C-nya tidak berbeda nyata satu dengan yang lain yaitu berkisar antara 0,60-0,62\%. Dengan demikian kandungan vitamin $\mathrm{C}$ pada muffin memang merupakan sumbangan dari puree pisang tongka langit. Menurut Tetelepta et al. (2015), kadar vitamin C pisang tongka langit yang diolah dengan cara dibakar yakni sebesar $2.77 \mathrm{mg}$.

Tabel 2. Karakteristik kimia muffin dengan konsentrasi puree pisang tongka langit yang berbeda

\begin{tabular}{lllll}
\hline Perlakuan & Kadar air $(\%)$ & Kadar abu (\%) & Total gula (\%) & Vitamin C (\%) \\
\hline Kontrol & $19,76 \pm 0,17^{\mathrm{d}}$ & $1,30 \pm 0,26^{\mathrm{a}}$ & $14,00 \pm 0,48^{\mathrm{b}}$ & $0,33 \pm 0,13^{\mathrm{b}}$ \\
$70 \%$ & $24,03 \pm 0,23^{\mathrm{c}}$ & $1,52 \pm 0,04^{\mathrm{a}}$ & $14,62 \pm 0,02^{\mathrm{b}}$ & $0,61 \pm 0,01^{\mathrm{a}}$ \\
$80 \%$ & $26,09 \pm 0,01^{\mathrm{b}}$ & $1,56 \pm 0,06^{\mathrm{a}}$ & $15,10 \pm 0,18^{\mathrm{b}}$ & $0,60 \pm 0,02^{\mathrm{a}}$ \\
$90 \%$ & $26,97 \pm 0,19^{\mathrm{a}}$ & $1,57 \pm 0,04^{\mathrm{a}}$ & $17,42 \pm 0,22^{\mathrm{a}}$ & $0,62 \pm 0,01^{\mathrm{a}}$ \\
\hline
\end{tabular}

Keterangan: Nilai yang diikuti huruf yang sama pada kolom yang sama tidak berbeda nyata berdasarkan uji Tukey $(\alpha=0,05)$. 
Tabel 3. Karakteristik hedonik muffin

\begin{tabular}{lcccc}
\hline Perlakuan & Rasa & Warna & Aroma & Overall \\
\hline Kontrol & 2,55 & 2,70 & 2,30 & 2,45 \\
$70 \%$ & 3,15 & 2,55 & 2,35 & 2,55 \\
$80 \%$ & 2,85 & 2,65 & 3,15 & 2,90 \\
$90 \%$ & 3,10 & 2,75 & 3,15 & 3,00 \\
\hline
\end{tabular}

Kadar vitamin $\mathrm{C}$ pada muffin yang lebih kecil dibandingkan pada puree pisang tongka langit disebabkan karena sedikitnya puree pisang yang digunakan, juga dikarenakan proses pemanasan berulang yang dialami puree pada saat pemanggangan muffin.

\section{Karakteristik organoleptik}

\section{Mutu Hedonik}

Karakteristik mutu hedonik muffin yang diuji meliputi warna, rasa, aroma, dan tekstur (Gambar 3). Muffin kontrol dan puree 80\% memiliki warna yang agak kuning (berada pada 2,00-2,99 skala garis) sedangkan muffin dengan $70 \%$ dan $90 \%$ puree pisang tongka langit dinilai panelis memiliki warna tidak kuning $(1,00-1,99)$.

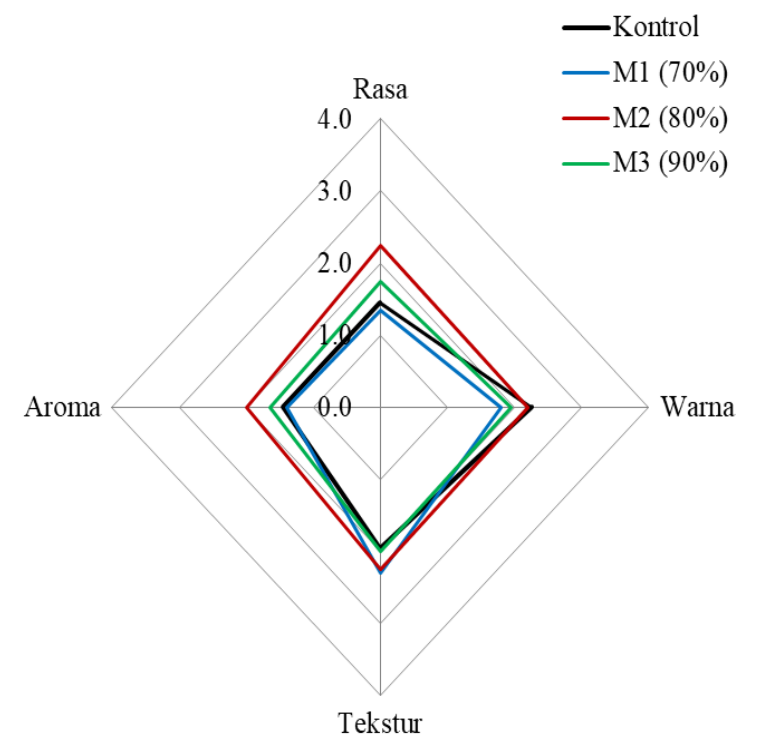

Gambar 3. Karakteristik mutu hedonik muffin

Makin banyak puree yang ditambahkan warna kuning pisang makin berkurang selama pemanggangan karena proses karamelisasi dari gula yang ada pada formulasi maupun dari gula yang berasal dari puree pisang tongka langit.

Mutu rasa yang dinilai panelis menunjukkan bahwa kontrol, $70 \%$ dan 90\% puree menghasilkan muffin yang tidak berasa pisang tongka langit berada diantara garis 1,00-1,99 sedangkan $80 \%$ menghasilkan muffin yang agak berasa pisang tongka langit (2,00-2,99). Muffin dengan $80 \%$ pisang tongka langit dinilai panelis masih mempertahankan rasa pisang tongka langit. Makin tinggi konsentrasi sampai $90 \%$ malah dinilai panelis makin kehilangan rasa pisang tongka langit.

Hal yang sama juga berlaku untuk aroma. Muffin kontrol, 70\%, dan 90\% puree dinilai panelis tidak beraroma pisang tongka langit $(1,00-1,99)$, sedangkan muffin dengan $80 \%$ puree memiliki aroma pisang tongka langit. Rasa dan aroma pisang tongka langit mulai muncul pada konsentrasi puree $80 \%$ namun hilang pada konsentrasi $90 \%$, hal ini diduga karena makin meningkatnya kandungan gula sejalan dengan meningkatnya konsentrasi puree sehingga karamelisasi yang terjadi makin tinggi menghasilkan rasa dan aroma karamelisasi (Purlis, 2010) yang mengurangi rasa dan aroma pisang tongka langit.

Penambahan puree pisang tongka langit dinilai panelis meningkatkan tekstur (kelembutan) dari muffin. Mufffin kontrol dinilai panelis tidak lembut $(1,00-1,99)$, sedangkan yang dengan puree pisang tongka langit $70 \%, 80 \%$, dan $90 \%$ memiliki tekstur yang agak lembut. Hal ini diduga disebabkan karena tekstur puree yang lembut mempengaruhi struktur remah muffin yang dihasilkan juga lembut. Hal yang sama juga diperoleh dengan penambahan puree papaya dalam pembuatan muffin untuk tekstur (Duffrin et al., 2001).

\section{Hedonik}

Karakteristik hedonik muffin dengan konsentrasi puree pisang tongka langit yang berbeda meliputi rasa, warna, aroma, dan overall (Tabel 3).

Atribut rasa bergantung pada komposisi bahan yang digunakan dalam pembuatan produk. Muffin dengan penambahan puree pisang tongka langit menaikkan tingkat kesukaan panelis dari 
agak suka $(2,5)$ kontrol) menjadi suka $(2,85-3,15)$. Peningkatan penilaian sensori pada atribut rasa akibat penambahan puree pisang tongka langit berhubungan dengan rasa manis pada muffin yang mengandung pisang tongka langit. Hal ini sejalan dengan meningkatnya kandungan total gula pada muffin dengan bertambahnya pisang tongka langit. Muffin dengan rasa sedikit lebih manis cenderung disukai panelis sehingga menaikan tingkat penerimaan panelis.

Warna merupakan faktor yang harus diperhatikan dalam pengembangan produk, karena konsumen menilai produk pertama kali pada penampakan visualnya. Panelis cenderung menyukai warna muffin baik tanpa penambahan maupun dengan penambahan puree pisang tongka langit yang berada pada kategori agak suka mendekati suka (2,55-2,75, Tabel 3).

Aroma merupakan salah satu sifat sensori yang diterima oleh indera pembau yang dapat mempengaruhi tingkat penerimaan sensori. Muffin kontrol dan yang dengan konsentrasi puree $70 \%$ agak disukai panelis $(2,30$ dan 2,35) sedangkan aroma muffin dengan $80 \%$ dan $90 \%$ puree lebih disukai panelis $(3,15$ dan 3,15$)$. Tingkat kesukaan panelis terhadap aroma diduga karena aroma pisang tongka langit dan aroma karamelisasi selama pemanggangan.

Tingkat kesukaan overall merupakan indikator tingkat penerimaan panelis secara keseluruhan terhadap produk muffin. Penambahan puree pisang tongka langit pada konsentrasi $80 \%$ dan $90 \%$ lebih disukai panelis $(2,90-3,00)$ daripada kontrol dan $70 \%(2,45-2,55)$.

\section{KESIMPULAN}

Penambahan puree pisang tongka langit dalam pembuatan muffin berpengaruh terhadap karakteristik kimia dan organoleptik, namun tidak berpengaruh terhadap volume pengembangan. Puree dengan konsentrasi $80 \%$ merupakan perlakuan yang tepat untuk menghasilkan muffin dengan karakteristik terbaik secara fisik, kimia dan organoleptik. Muffin dengan puree pisang tongka langit $80 \%$ memiliki volume pengembangan $118 \%$, kadar air 26,09\%, kadar abu 1,56\%, kadar vitamin C $0,60 \%$, total gula $15,10 \%$ dan lebih disukai panelis pada kategori aroma dan overall serta lebih mempertahankan karakteristik pisang tongka langit pada muffin.

\section{DAFTAR PUSTAKA}

Abbas, S., C.D. Wei, K. Hayat, and Z. Xiaoming. 2012. Ascorbic acid: Microencapsulation techniques and trends - A review. Food Reviews International 28: 343-374. DOI: 10.1080/87559129.2011.635390

Acosta, K., G. Cavender, and W. L. Kerr. 2011. Sensory and physical properties of muffins made with waxy whole wheat flour. Journal of Food Quality 34: 343-351 DOI: 10.1111/j.1745-4557.2011.00401.x

Albanjar, F.V., E. Nurali, L. Lalujan, dan T. Langi. 2014. Evaluasi kualitas sensoris muffin berbahan baku pisang goroho (Musa acuminate sp.). Cocos 5. https://ejournal.unsrat.ac.id/index.php/cocos/ article/download/5835/5368

Arifin, N., M.A. S.N. Izyan, and N. Huda-Faujan. 2019. Physical properties and consumer acceptability of basic muffin made from pumpkin puree as butter replacer. Food Research 3: 840-845.

Astasari, A. 2016. Subtitusi Puree Pisang Pada Pembuatan Banana Muffin Dan Tepung Pisang Pada Pembuatan Banana Cheese Stick. Skripsi. Universitas Negeri Yogyakarta. Yogyakarta.

Caramena, V. and G. Wang. 2016. The epigenetic role of vitamin $\mathrm{C}$ in health and disease. Cellular and Molecular Life Sciences 73: 1645-1658. DOI: 10.1007/s00018-0162145-x

Conforti, F.D. 2006. Cake manufacture. In Hui, Y. H. Bakery Products: Science and Technology. Blackwell Publishing, USA. pp 393-410.

Duffrin, M.W., D.H. Holben, and M.J. Bremner. 2001. Consumer acceptance of pawpaw (Asimina triloba) fruit puree as a fatreducing agent in muffins, compared to muffins made with applesauce and fat. Family and Consumer Sciences Research Journal 29: 281-287 DOI: 10.1177/1077727X01293005.

El Khoury, D., S. Balfour-Ducharme, and I.J. Joye. 2018. A review on the gluten-free diet: Technological and nutritional challenges. 
Nutrients $\quad 10: \quad 1410 . \quad$ DOI:

10.3390/nu10101410

Englberger, L. 2003. Carotenoid-rich bananas in Micronesia. Info Musa 12. The International journal on Banana and Plantain 2: 1-11.

Häkkinen, M., H. Väre, and M.J.M. Christenhusz. 2012. Identity of a Pisang - historical concepts of Musa (Musaceae) and the reinstatement of Musa troglodytarum. Folia Malaysiana 13: 1-14.

Hanani, N.R. 2015. Eksperimen Pembuatan Muffin Bahan Dasar Tepung Terigu Substitusi Tepung Ganyong. Skripsi. Universitas Negeri Semarang.

Hartley, J., E. Goodman, K. Coate, and P. Terry. 2017. The effect of replacing added sugar with fig puree on the nutritional, physical, and sensory characteristics of carrot cake muffins. Journal of The Academy of Nutrition and Dietetics 117: Supplemen A9. DOI: 10.1016/j.jand.2017.06.099

Jauharah, M.Z.A., W.R.W. Rosli, and S.D. Robert. 2014. Physicochemical and sensorial evaluation of biscuit and muffin incorporated with young corn powder. Sains Malaysiana 43: 45-52.

Lahane, I. 2019. Pengaruh Lama Blanching Terhadap Karakteristik Kimia dan Organoleptik Puree Pisang Tongka Langit. Skripsi. Fakultas Pertanian Universitas Pattimura. Ambon.

Mamat, H., J.Md.H. Akanda, M.K. Zainol, and Y.A. Ling. 2018. The influence of seaweed composite flour on the physicochemical properties of muffin. Journal of Aquatic Food Product Technology 27: 635-642 DOI: 10.1080/10498850.2018.1468841

Manaf, M. A., N. A. Othman, S. Harith, and W. R. W. Ishak. 2016. Thermal properties of batter and crumb structure of muffin incorporated with Persea americana puree. Journal of Culinary Science and Technology 15: 259271 DOI: $10.1080 / 15428052.2016 .1249041$

Matos, M.E., T. Sanz, and C.M. Rosell. 2014. Establishing the functions of proteins on the rheological and quality properties of rice bread gluten free muffins. Food Hydrocolloids 35: 150-168. DOI: 10.1016/j.foodhyd.2013.05.007

Othman, N.A., M.A. Manaf, S. Harith, and W.R.W. Ishak. 2018. Influence of avocado puree as a fat replacer on nutritional, fatty acid and organoleptic properties of low-fat muffin. Journal of The American College of Nutrition 37: 583-588. DOI: 10.1080/07315724.2018.1451408

Purlis, E. 2010. Browning development in bakery product - A review. 2010. Journal of Food Engineering 99: 239-249. DOI: 10.1016/j.jfoodeng.2010.03.008

Rismaya, R., E. Syamsir, dan B. Nurtama. 2018. Pengaruh penambahan tepung labu kuning terhadap serat pangan, karakteristik fisikokimia dan sensori muffin. Jurnal Teknologi dan Industri Pangan 29: 58-68.

Samson, E, H. Semangun, dan F. S. Rondonuwu. 2013. Analisis kandungan karotenoid ekstrak kasar buah pisang tongkat langit (Musa Troglodytarum) dengan menggunakan Spektroskopi Nir (Near Infrared). Traditional Medicine Journal 18: 17-21.

Samson, E., M. Sopacua, dan L. Eddy. 2019. Efek jus pisang tongka langit (Musa troglodytarum) terhadap ginjal mencit (Mus musculus) model malaria. Eksakta 19: 154168. DOI: 10.20885/eksakta.vol19.iss2.art6

Setyaningsih, D., A. Apriyantono, dan M.P. Sari. 2010. Analisis Sensori Untuk Industri Pangan Dan Agro. Bogor: IPB Pres.

Shevkani, K. and N. Singh. 2014. Influence of kidney bean, field pea and amaranth protein isolates on the characteristics of starch-based gluten-free muffins. International Journal of Food Science and Tecchnology 49: 22372244. DOI:10.1111/ijfs.12537

Srinivasamurthy, S., M. Yadav, S. Sahay, and A. Singh. 2017. Development of muffin by incorporation of dried Moringa oleifera (drumstick) leaf powder with enhanced micronutrient content. International Journal of Food Science and Nutrition 2: 173-178.

Tetelepta, G., J. Talahatu, dan S. Palijama. 2015. Pengaruh cara pengolahan terhadap sifat fisikokimia pisang tongka langit (Musa troglodytarum). Agritekno: Jurnal Teknologi Pertanian 4: 14-18.

Tuhumury, H.C.D., E. Moniharapon, dan A. Souripet. 2018. Karakteristik sensoris puree pisang tongka langit pendek (Musa troglodytarum). Jurnal Teknologi Pertanian 5: 1-10.

Tuhumury, H.C.D., D.M. Small, and L. Day. 2014. The effect of sodium chloride on gluten network formation and rheology. Journal of 
Cereal Science 60: 224-237. DOI: 10.1016/j.jcs.2014.03.004

Wilderjans, E., B. Pareyt, H. Goesaert, K. Brijs, and J.A. Delcour. 2008. Role of gluten in a pound cake system: a model approach based on gluten-starch blends. Food Chemistry
110:

909-915.

DOI:

10.1016/j.foodchem.2008.02.079.

Wulandari, E. dan E. Lembong. 2016. Karakteristik roti komposit ubi jalar dengan penambahan $\alpha$-amilase dan glukoamilase. Jurnal Penelitian Pangan 1: 1-6.

Copyright @ 2020 Helen C. D. Tuhumury, Agustina Souripet, Michael Warlauw (c) (1) (2)

This work is licensed under a Creative Commons Attribution-ShareAlike 4.0 International License. 